\title{
PENGARUH SIKLUS OPERASI DAN SIKLUS KONVERSI KAS TERHADAP LIKUIDITAS PERUSAHAAN
}

\author{
Oleh : \\ Enung Nurhayati dan Yoyon Supriadi \\ Sekolah Tinggi Ilmu Ekonomi Kesatuan
}

\begin{abstract}
One of Indicator success at the company can be seen from the company's ability to generate profits, but the profits of an enterprise does not reflect the amount of cash that is in company. Besides needed supplies sufficient cash, the company can also be seen from the operating cycle in which the company involving investment in inventories (inventories) and receivables (accounts receivable) and make the payments on their debts ( accounts payable). Operating cycle is very important to detect and prevent any potential threat of liquidity. As well as a major tool in formulating a grand strategy to bring the company out of the crisis and return to the point of liquidity ideal ( normal ). Which can be taken into consideration by the company is the cash conversion cycle in which companies to acquire and convert the non- cash assets into cash .

The purpose of this study was to determine the operating cycle and cash conversion cycle for the company's liquidity study was conducted at PT. Mayora Indah Tbk ,. PT . Ultrajaya Milk Industry \& Trading Company Tbk, . and PT. Sekar Laut Tbk . for ten years from 2005 to 2014. In this study the data used operating cycle, the cash conversion cycle and financial statements (balance sheet and income statement) PT. Mayora Indah Tbk, PT. Ultrajaya Milk Industry \& Trading Company Tbk, dan PT. Sekar Laut Tbk, period 2005 to 2014. Analysis of the data used is the linear regression analysis, the correlation coefficient and the coefficient of determination, $T$ test and $F$ test

The study concluded that the results of the partial operation cycle no significant effect on the liquidity of PT. Sekar Laut Tbk, because the value is greater than 0,243 sig standard error or alpha ( a ) of 5\%. Cash conversion cycle partially no significant effect on the liquidity of PT. Sekar Laut Tbk since sig 0.084 greater than the standard error or alpha ( $a)$ of $5 \%$, and the operating cycle and the simultaneous conversion cycle no significant effect on the liquidity of PT. Sekar Laut Tbk since sig 0.193 greater than the standard error or alpha $(a)$ of $5 \%$.
\end{abstract}

Keyword : Operating Cycle, Cash Conversion Cycle, Liquidity

\section{PENDAHULUAN}

Ilmu pengetahuan dan teknologi yang semakin berkembang telah menyebabkan terjadinya globalisasi pada berbagai bidang kehidupan manusia, termasuk di dalamnya globalisasi pada bidang ekonomi khususnya kegiatan perdagangan atau bisnis. Dengan semakin berkembangnya dunia usaha dewasa ini, maka persaingan antar perusahaan khususnya pada perusahaan yang sejenis akan semakin ketat. Untuk menjaga kelangsungan hidup perusahaan dalam menghadapi persaingan yang ketat tersebut, maka di perlukan suatu penanganan dan pengelolaan sumber daya yang di miliki oleh perusahaan secara efisien dan efektif juga di tuntut untuk dapat menghasilkan keputusan-keputusan yang menunjang terhadap pencapaian tujuan perusahaan di masa yang akan datang. 
Salah satu sumber daya yang dikelola dengan benar adalah kas, karena adanya persediaan kas yang cukup memungkinkan suatu perusahaan dalam melaksanakan aktivitasnya agar tidak mengalami kesulitan dan hambatan yang mungkin akan timbul selain dibutuhkan persediaan kas yang cukup, perusahaan juga dapat dilihat dari siklus operasi dimana perusahaan yang melibatkan penanaman modal pada persediaan (inventories) dan piutang (account receivable) serta melakukan pembayaran atas hutang-hutangnya (account payable). Mengetahui siklus operasi sangat penting untuk mendeteksi dan mencegah setiap kemungkinan ancaman likuiditas. Sekaligus menjadi piranti utama dalam menyusun 'grand strategi' untuk membawa perusahaan keluar dari krisis dan kembali ke titik likuiditas yang ideal (normal). Dalam kalimat singkat, siklus operasi (operating cycle) suatu perusahaan adalah jumlah hari yang dibutuhkan untuk mengkoversikan 'barang persediaan' dan 'piutang' menjadi 'kas' (masuk). Semakin pendek siklus operasi semakin bagus. Siklus operasi atau operating cycle bisa dihitung dengan cara menjumlahkan 'usia rata-rata persediaan' dengan waktu rata-rata penagihan piutang'. Semakin pendek siklus operasi maka semakin cepat kas terisi dan kas tersebut bisa digunakan untuk membiayai kewajiban jangka pendek. Jadi operating cycle berhubungan dengan kas.

Yang dapat diperhatikan juga oleh perusahaan selain siklus operasi adalah siklus konversi kas dimana perusahaan untuk mendapatkan dan mengkonversikan aktiva non kas menjadi kas.Sedangkan untuk mengetahui siklus konversi kas aliran kas keluar perusahaan digunakan untuk melakukan pembelian persediaan yang akan di produksi untuk menghasilkan barang, kemudian akan di jual kembali baik secara tunai mau pun kredit. Penjualan secara kredit tidak akan menimbulkan kas pada saat terjadi penjualan,tetapi menimbulkan piutang dagang. Piutang dagang akan berubah menjadi kas apabila piutang dagang telah dilunasi pada saat jatuh tempo.

Semakin singkat siklus konversi kas dalam periode perusahaan dengan memproses dan menjual barang lebih cepat maka semakin baik, dikarenakan semakin sedikit biaya yang dikeluarkan untuk kegiatan operasi perusahaan. Semakin singkat siklus konversi kas dalam periode penerimaan piutang dengan mempercepat penagihan maka semakin besar kas/dana yang masuk pada perusahaan, baik itu akan digunakan untuk kegiatan operasi perusahaan maupun digunakan untuk menyelesaikan kewajiban-kewajiban jangka pendek perusahaan tersebut. Dengan melihat tingkat likuiditas dan siklus konversi kas suatu perusahaan dari tahun ke tahun dapat dapat diketahui apakah terjadi kenaikan atau penurunan tingkat likuiditas dan siklus konversi kas pada perusahaan tersebut

Ketersediaan kas yang cukup dapat mempengaruhi likuiditas karena Likuiditas sangat diperlukan oleh sebuah perusahaan sebagai pemenuhan kewajiban jangka pendeknya. Rasio likuiditas digunakan untuk mengukur kemampuan perusahaan dalam memenuhi kewajiban financial yang harus dipenuhi dalam jangka pendek. Likuiditas menunjukkan kemampuan perusahaan untuk membayar kewajiban jangka pendek tepat pada waktunya. Likuiditas perusahaan ditunjukkan oleh besarnya aktiva lancar yaitu aktiva yang mudah diubah menjadi kas yang meliputi kas, surat berharga, piutang dari persediaan. Namun komponen yang digunakan dalam penulis ini adalah tentang siklus yang ada dalam perusahaan yaitu siklus operasi dan siklus konversi kas yang ada hubungan nya dengan kas, piutang, dan persediaan.

Berbagai skenario ini melihatkan penyebab likuiditas ukuran likuiditas sangat berpengaruh dalam suatu perusahaan. Jika suatu perusahaan dapat memenuhi kewajiban lancarnya, maka kelangsungan usahanya dipertanyakan. Dilihat dri sisi lain, semua ukuran analisis menjadi kurang penting dibandingkan likuiditas. Meskipun ukuran akuntansi mengasumsikan kelangsungan hidup perusahaan, analisis perlu selalu menilai keabsahan asumsi ini dengan menggunakan ukuran likuiditas.

Berdasarkan latar belakang penelitian yang telah dikemukakan tersebut, maka penulis memilih judul "Pengaruh Siklus Operasi dan Siklus Konversi Kas

\section{Terhadap Likuiditas Perusahaan"}

\section{Identifikasi Masalah}

Sebagaimana telah dikemukakan diatas, maka penulis mengidentifikasi permasalahan tersebut sebagai berikut :

1. Bagaimana kondisi siklus operasi, siklus konversi kas dan likuiditas pada PT. Mayora Indah Tbk, PT. Ultrajaya Milk Industry Trading Co Tbk, dan PT. Sekar Laut Tbk.? 
2. Bagaimana pengaruh siklus operasi dan siklus konversi kas terhadap likuiditas, baik secara parsial maupun simultan?

3. Seberapa besar pengaruh siklus operasi mempengaruhi likuiditas pada PT. Mayora Indah Tbk, PT. Ultrajaya Milk Industry Trading Co Tbk, dan PT. Sekar Laut Tbk, ?

4. Seberapa besar pengaruh siklus konversi kas mempengaruhi likuiditas pada PT. Mayora Indah Tbk, PT. Ultrajaya Milk Industry Co Tbk, dan PT. Sekar Laut Tbk ?

5. Seberapa besar pengaruh siklus operasi dan siklus konversi kas dapat mempengaruhi likuiditas pada PT. Mayora Indah Tbk, PT. Ultrajaya Milk Industry Trading Co Tbk ?

\section{Maksud dan Tujuan Penelitian}

1. Untuk mengetahui bagaimana kondisi siklus operasi, siklus konversi kas dan likuiditas pada PT. Mayora Indah Tbk, PT. Ultrajaya Milk Industry Trading Co Tbk, dan PT. Sekar Laut Tbk.

2. Untuk mengetahui seberapa besar pengaruh siklus operasi, siklus konversi kas terhadap perusahaan, baik secara simultan maupun parsial

3. Untuk mengetahui siklus operasi dapat mempengaruhi likuiditas pada PT. Mayora Indah Tbk, PT. Ultrajaya Milk Industry Trading Co Tbk, dan PT. Sekar Laut Tbk.

4. Untuk mengetahui siklus konversi kas mempengaruhi likuiditas pada PT. Mayora Indah Tbk, PT. Ultrajaya Milk Industry Trading Co Tbk, dan PT. Sekar Laut Tbk.

5. Untuk mengetahui siklus operasi dan siklus konversi kas dapat mempengaruhi likuiditas pada PT. Mayora Indah Tbk, PT. Ultrajaya Milk Industry Trading Co Tbk, dan PT. Sekar Laut Tbk.

\section{TINJAUAN PUSTAKA}

\section{Siklus Operasi}

Siklus operasi dapat diartikan sebagai periode waktu rata-rata antara pembelian persediaan dengan pendapatan kas yang nantinya akan diterima penjual. Atau rangkaian seluruh transaksi dimana suatu bisnis menghasilkan penerimaannya dan penerimaan kasnya dari pelanggan. Siklus operasi suatu perusahaan terdiri dari transaksi-transaksi sebagai berikut :

1. Pembelian barang

2. Penjualan barang, dan

3. Pengumpulan piutang dari pelanggan

Siklus operasi $=$ Usia Rata-rata Persediaan + Waktu Rata-rata Penagihan Piutang

\section{Siklus Konversi Kas}

Siklus konversi kas adalah periode antara pembelian bahan dan penjualan produk, waktu antara perolehan bahan baku dan penerimaan pembayaran dari penjualan produk jadi.

Siklus konversi kas merupakan siklus dimana perusahaan membeli persediaan, menjual barang dagangan secara kredit, dan kemudian menagihkan piutang tersebut . Siklus konversi kas menunjukkan berapa lama waktu antara pembayaran untuk modal kerja dan penagihan kas dari penjualan modal kerja tersebut. Pada umumnya perusahaan menjual bahan secara kredit. Karena itu perusahaan harus menyediakan sejumlah kas untuk mendanai siklus operasinya sejak barang dagangan di terima di gudang, dijual secara kredit, dan piutang usaha tertagih.

\section{Likuiditas}

Likuiditas merupakan salah satu aspek keuangan yang penting untuk danalisis. Hal tersebut dikarenakan likuiditas merupakan salah satu alat yang dapt digunakan untuk mengukur keberhasilan suatu perusahaan yang dilihat dari seberapa besar kemampuan perusahaan dalam memenuhi kewajiban lancarnya.

Menurut Gitman (2009, 52) "Liquidity is a firm's ability is short-term obligations as they come due". Yang artinya likuiditas adalah kekuatan suatu perusahaan untuk kepuasan obligasi jangka pendek sebagai waktu jatuh temponya. 


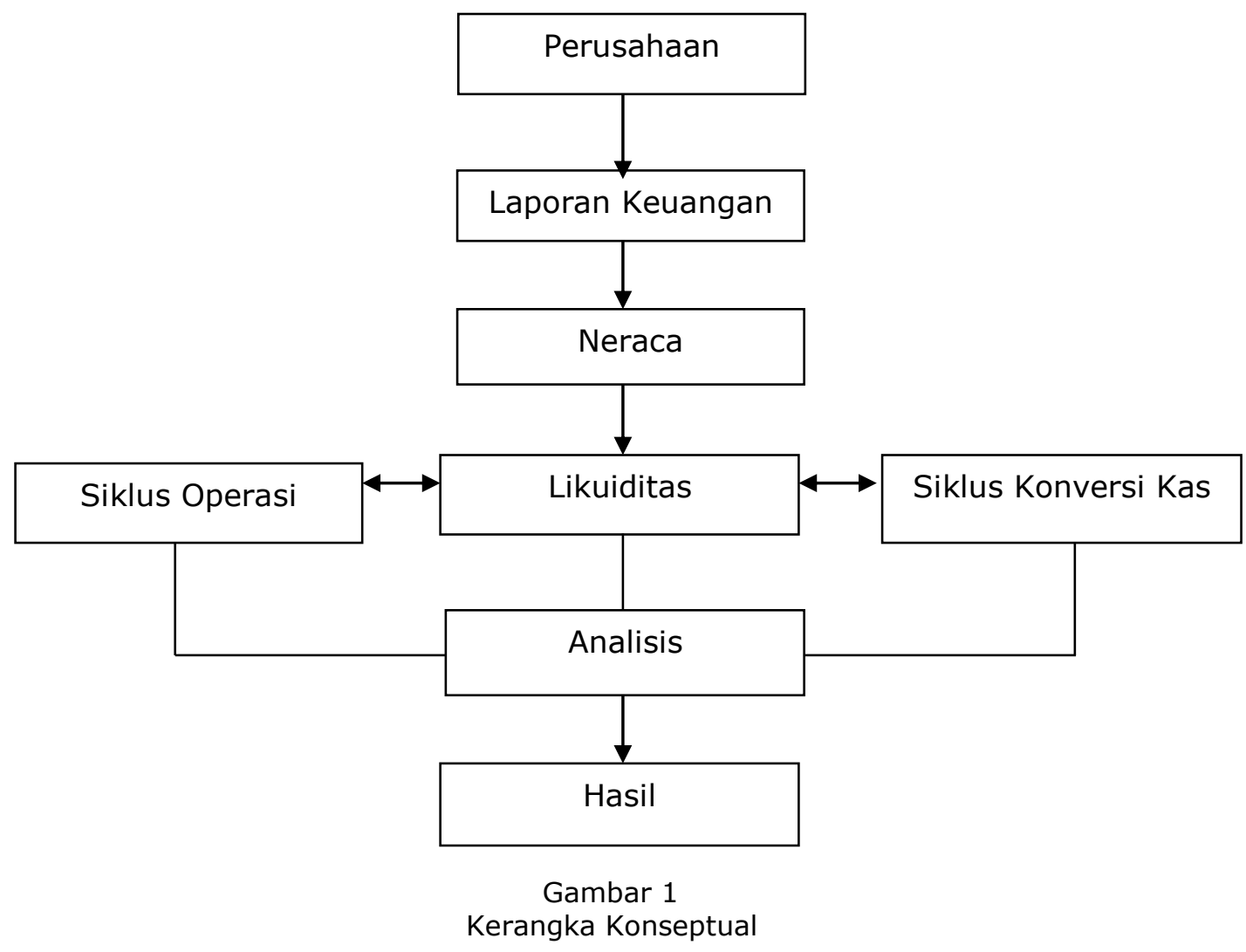

\section{Hipotesis Penelitian}

1. Hipotesis Penelitian

Hipotesis menurut Erlina $(2007,41)$, "Menyatakan hubungan yang diduga secara logis antara dua variabel atau kebih dalam rumusan proporsisi yang dapat diuji secara empiris". Hipotesis dari penelitian yang akan dilakukan berdasrkan permasalahan dan tujuan yang ingin dicapai adalah sebagai berikut:

H1 : Pengaruh siklus operasi terhadap likuiditas perusahaan.

$\mathrm{H} 2$ : Pengaruh siklus konversi kas terhadap likuiditas perusahaan.

H3 : Pengaruh siklus operasi dan siklus konversi kas terhadap likuiditas perusahaan.

2. Hipotesis Statistik

Hipotesis dapat bersifat kuantitaf dan kualitatif. Secara statistic, hipotesis yang bersifat kualitatif tidak dapat diuji adalah hipotesis yang bersifat kuantitatif. Hipotesis yang demikian tersebut hipotesis statistic (Statistical Hypotesis) karena selain harus disajikan dalam bentuk angka, hipotesis statistik juga merupakan pernyataan tentang bentuk fungsi yang menggambarkn hubungan antar variable yang teliti.

Secara statistika terdapat dua macam hipotesis, yaitu Hipotesis s Nol (Null Hypotesis) yang diberi symbol dengan $\mathrm{Ho}$, dan hipotesis alternative (alternative Hypotesis) yang diberi symbol Ha. Hipotesis Nol menyatakan tidak ada perbedaan antara dua variabel atau lebih. Hipotesis alternative menyatakan terdapat perbedaan antara statistic sampel dengan parameter populasi atau terdapat hubungan antara dua variabel atau lebih.

\section{METODOLOGI PENELITIAN}

Metode penelitian yang dilakukan pada dasarnya adalah untuk mengembangkan teori dan pemecahan masalah melalui analisa yang sistematis. Dalam penelitian ini 
penulis menggunakan metode deskriptif komperatif. Metode ini dipakai bertujuan untuk menjawab pertanyaan mengenai pengaruh tingkat inflasi dan nilai tukar rupiah terhadap profitabilitas perusahaan. Metode penelitian ini adalah salah satu metode yang dilakukan dengan cara mencari data yang dapat memberikan gambaran yang jelas mengenai profitabilitas perusahaankemudian penulis membandingkan perkembangan profitabilitas perusahaan tiap tahunnya dengan mengambil data selama lima tahun terakhir. Metode ini tersusun sebagai berikut :

1. Analisa deskriptif

Yaitu studi yang dilakukan dengan cara menguraikan dan menjelaskan variabel penelitian yang dilakukan penulis

2. Analisa Komparatif

Yaitu studi yang dilakukan untuk membandingkan antara hasil penelitian dari satu perusahaan dengan perusahaan lainnya.

3. Analisa Statistika

Analisis statistika digunakan penulis untuk menganalisis pengaruh dari variabel independent terhadap variabel dependent. Model ini dipilih karena penelitian ini dirancang untuk menentukan variabel independent yang mempunyai pengaruh terhadap variabel dependent.

\section{Operasional Variabel}

Untuk lebih mempermudah penulis dalam melakukan penelitian, maka penulis melakukan operasionalisasi dari variable-variabel yang saling berkaitan. Dengan kata lain, penelitian dijabarkan lebih lanjut kedalam indicator dan pengukuran sebagai berikut :

Berikut ini merupakan tabel operasionalisasi variabel "pengaruh siklus operasi dan siklus konversi ks terhadap likuiditas perusahaan".

Tabel 1

Operasionalisasi Variabel

\begin{tabular}{|c|c|c|}
\hline Variabel & Indikator & Skala atau Ukuran \\
\hline Siklus operasi & Operating Cycle & Rasio \\
\hline Siklus konversi kas & Cash Conversion Cycle \\
\hline Likuiditas & Current Rasio & Rasio \\
\hline
\end{tabular}

\section{Metode Analisis}

Metode analisis yang dilakukan penulis untuk memperoleh dan menganalisis data-data yang terkumpul dalam penulisan skripsi ini adalah dengan menggunakan metode analisis deskriptif kauntitatif. Terlebih dahulu penulis melakukan metode analisi regresi linear sederhana.

\section{Analisis Regresi}

Analisis regresi adalah suatu proses untuk memperoleh suatu hubungan fungsional antara variable acak $Y$ denagn variabel $X$. Persamaan regresi digunakan untuk memprediksi nilai $Y$ untuk nilai $X$ tertentu

Adapun rumus regresi adalah sebagai berikut:

$Y=a+b X_{1}+b X_{2}$

Keterangan :

Y $\quad$ Volume Penjualan

$\mathrm{a}=$ Konstanta

$\mathrm{b} \quad=$ Koefisien regresi

$\mathrm{X}_{1}=$ Siklus Operasi

$\mathrm{X}_{2}=$ Siklus Konversi Kas

Uji Hipotesis

a. Uji t (secara parsial)

Uji t dilakukan untuk mengetahui besarnya pengaruh masing-masing variabel bebas yaitu siklus operasi dan siklus konversi kas secara parsial (individual) 
terhadap variabel terikatnya yaitu likuiditas perusahaan. Nilai dari uji t dapat dilihat dari $p$-value pada masing-masing variabel bebas, atau dengan membandingkan nilai thitung dengan ttabel. Adapun kriteria pengujiannya adalah sebagai berikut:

- Ho diterima dan Ha ditolak apabila thitung< ttabel. Berarti variabel bebas tidak berpengaruh secara signifikan terhadap variabel terikat.

- Ho ditolak dan Ha diterima apabila thitung > ttabel. Berarti variabel bebas berpengaruh secara signifikan terhadap variabel terikat.

b. Uji F (secara simultan)

Uji F dilakukan untuk menguji model penelitian apakah perubahan siklus operasi dan siklus konversi kas secara simultan berpengaruh secara signifikan terhadap likuiditas perusahaan. Uji $\mathrm{F}$ dilakukan dengan cara membandingkan nilai Fhitung dengan Ftabel. Adapun kriteria pengujiannya adalah sebagai berikut:

- Ho diterima dan Ha ditolak apabila Fhitung < Ftabel. Artinya variabel bebas secara bersama-sama tidak berpengaruh secara signifikan terhadap variabel terikat.

- Ho ditolak dan Ha diterima apabila Fhitung> Ftabel. Artinya variabel bebas secara bersama-sama berpengaruh secara signifikan terhadap variabel terikat.

\section{Koefisien Korelasi}

Koefisien korelasi yaitu kekuatan hubungan anatara 3 variabel yaitu $X_{1}$ (Siklus Operasi), $X_{2}$ (Siklus Konversi Kas) terhadap $Y$ (Likuiditas), biasanya koefisien korelasi dilambangkan dengan symbol " $r$ ". Nilai koefisien $r$ akan selalu berada di antara -1 sampai +1 .

\section{Koefisien Determinasi}

Analisis koefisien determinasi yaitu untuk melihat persentase (\%) pengaruh variabel $X_{1}$ (Siklus Operasi), $X_{2}$ (Siklus Konversi Kas) terhadap $Y$ (Likuiditas) dengan rumus sebagi berikut

$\mathrm{KD}=\mathrm{r}^{2} \times 100 \%$

Dimana:

$\mathrm{KD}=$ Koefisien determinasi

$r^{2}=$ Kuadrat dan korelasi ganda

\section{HASIL DAN PEMBAHASAN}

1. Pengaruh antara siklus operasi secara parsial terhadap likuiditas

a. Pengaruh antara siklus operasi secara parsial terhadap likuiditas PT. Mayora Indah Tbk dapat dilihat dari output SPSS di bawah ini

Tabel 1

Coefficient siklus operasi terhadap likuiditas PT. Mayora Indah Tbk

\begin{tabular}{|c|c|c|c|c|c|c|}
\hline \multicolumn{7}{|c|}{ Coefficients $^{a}$} \\
\hline \multirow{2}{*}{\multicolumn{2}{|c|}{ Model }} & \multicolumn{2}{|c|}{ Unstandardized Coefficients } & \multirow{2}{*}{$\begin{array}{c}\text { Standardized } \\
\text { Coefficients } \\
\text { Beta }\end{array}$} & \multirow[b]{2}{*}{$\mathrm{t}$} & \multirow[b]{2}{*}{ Sig. } \\
\hline & & $\mathrm{B}$ & Std. Error & & & \\
\hline \multirow[t]{3}{*}{1} & (Constant) & 2.195 & 1.847 & & 1.189 & .269 \\
\hline & Siklus & .004 & .015 & .096 & .272 & .792 \\
\hline & Operasi & & & & & \\
\hline
\end{tabular}

a. Dependent Variable: likuiditas 
Berdasarkan table 4.2.1 (Coefficients) di atas, maka pengaruh antara Siklus Operasi (SO) terhadap Likuiditas pada PT. Mayora Indah, Tbk dapat diketahui dalam persamaan regresi sebagai berikut:

$\mathrm{Y}=0,2195-0,004$

Dimana: $\quad Y=$ Likuiditas

$$
X=\text { Siklus Operasi (SO) }
$$

Persamaan diatas menunjukkan bahwa siklus operasi memiliki pengaruh yang negatif terhadap likuiditas perusahaan. Persamaan diatas dapat diartikan bahwa setiap kenaikan siklus operasi sebesar 1 satuan maka likuiditas akan mengalami penurunan sebesar 0,004 sedangkan setiap penurunan siklus operasi masing-masing sebesar 1 satuan maka likuiditas akan mengalami kenaikan sebesar 0,004. Intercept sebesar 0,2195 menunjukkan bahwa apabila siklus operasi tidak mengalami perubahan maka akan berada pada posisi yang stabil sebesar 0,2195.

Dari tabel diatas maka dapat dilakukan uji $\mathrm{T}$ dengan ketentuan terdapat pengaruh yang signifikan apabila Thitung lebih besar dari Ttabel (Thitung > Ttabel). Uji T menunjukkan terdapat pengaruh yang signifikan antara nilai tukar rupiah terhadap profitabilitas perusahaan karena dari tabel diatas dapat dilihat Thitung statistic yang diperoleh sebesar 0,272 sedangkan Ttabel yang diperoleh sebesar 1,860. Hal ini dapat disimpulkan bahwa Thitung lebih kecil dibandingkan Ttabel $(0,272<1,860)$, maka hal ini mengindikasikan bahwa siklus operasi tidak memiliki pengaruh yang signifikan terhadap likuiditas perusahaan.

Selain dengan membandingkan antara Thitung dengan Ttabel, tingkat signifikansi juga dapat diketahui dengan membandingkan nilai Sig. pada table diatas dengan standar kesalahan atau alpha (a). Apabila nilai Sig. lebih kecil dari alpha (nilai Sig. < alpha) maka dapat dikatakan signifikan. Dalam penelitian ini penulis menggunakan alpha sebesar 0,05 dan Nilai Sig. Pada tabel diatas adalah 0,792 sehingga dapat dikatakan tidak terdapat pengaruh yang signifikan antara siklus operasi terhadap likuiditas perusahaan karena nilai Sig. lebih besar dibandingkan alpha $(0,792>0,05)$.

Dari uraian diatas hasil hipotesis statistik 1 adalah Ho1 diterima dan Ha1 ditolak dengan kesimpulan bahwa tidak ada pengaruh yang signifikan antara siklus operasi $\left(\mathrm{X}_{1}\right)$ terhadap likuiditas $(\mathrm{Y})$.

b. Pengaruh Siklus Operasi terhadap Likuiditas PT. Ultrajaya Milk Industry \& Trading Co Tbk

Tabel 2

Coefficient SO terhadap likuiditas PT. Ultrajaya Milk Industry \& Trading Co, Tbk

\begin{tabular}{|c|c|c|c|c|c|c|}
\hline \multicolumn{7}{|c|}{ Coefficients $^{a}$} \\
\hline \multirow{2}{*}{\multicolumn{2}{|c|}{ Model }} & \multicolumn{2}{|c|}{ Unstandardized Coefficients } & \multirow{2}{*}{$\begin{array}{l}\text { Standardized } \\
\text { Coefficients } \\
\text { Beta }\end{array}$} & \multirow[b]{2}{*}{$\mathrm{t}$} & \multirow[b]{2}{*}{ Sig. } \\
\hline & & $\mathrm{B}$ & Std. Error & & & \\
\hline \multirow[t]{2}{*}{1} & (Constant) & 2.869 & 1.114 & & 2.576 & .033 \\
\hline & $\begin{array}{l}\text { Siklus } \\
\text { operasi }\end{array}$ & -.006 & .008 & -.255 & -.747 & .477 \\
\hline
\end{tabular}

a. Dependent Variable: likuiditas

Untuk mengetahui besarnya pengaruh antara siklus operasi terhadap likuiditas perusahaan dapat diketahui dari persamaan regresi yang diperoleh dari tabel diatas : $Y=0,2.869-0,006 X$

Dimana : $\quad Y=$ Likuiditas

$$
X=\text { Siklus Operasi }
$$


Persamaan diatas menunjukkan bahwa siklus operasi memiliki pengaruh yang negatif terhadap likuiditas perusahaan. Persamaan diatas dapat diartikan bahwa setiap kenaikan siklus operasi sebesar 1 satuan maka likuiditas akan mengalami penurunan sebesar 0,006 (tanda negative diabaikan) sedangkan setiap penurunan siklus operasi masing-masing sebesar 1 satuan maka profitabilitas akan mengalami kenaikan sebesar 0,006. Intercept sebesar 2,869 menunjukkan bahwa apabila siklus operasi tidak mengalami perubahan maka likuiditas akan berada pada posisi yang stabil sebesar 2,869.

Dari tabel diatas maka dapat dilakukan uji $\mathrm{T}$ dengan ketentuan terdapat pengaruh yang signifikan apabila Thitung lebih besar dari Ttabel (Thitung > Ttabel). Uji $T$ menunjukkan terdapat pengaruh yang signifikan antara nilai tukar rupiah terhadap profitabilitas perusahaan karena dari tabel diatas dapat dilihat Thitung statistic yang diperoleh sebesar 0,747 (tanda negative diabaikan) sedangkan Ttabel yang diperoleh sebesar 1,860. Hal ini dapat disimpulkan bahwa Thitung lebih kecil dibandingkan Ttabel $(0,747<1,860)$, maka hal ini mengindikasikan bahwa siklus operasi tidak memiliki pengaruh yang signifikan terhadap likuiditas perusahaan.

Dari uraian diatas hasil hipotesis statistik 1 adalah Ho1 diterima dan Ha1 ditolak dengan kesimpulan bahwa tidak ada pengaruh yang signifikan antara nilai tukar rupiah $\left(\mathrm{X}_{1}\right)$ terhadap kemampulabaan $(\mathrm{Y})$.

c. Pengaruh Siklus Operasi terhadap Likuiditas PT. Sekar Laut Tbk

Tabel 3

Coefficients siklus operasi tehadap likuiditas PT. Sekar Laut Tbk

\section{Coefficients ${ }^{a}$}

\begin{tabular}{|c|c|c|c|c|c|c|}
\hline \multirow{2}{*}{\multicolumn{2}{|c|}{ Model }} & \multicolumn{2}{|c|}{ Unstandardized Coefficients } & $\begin{array}{c}\text { Standardized } \\
\text { Coefficients }\end{array}$ & \multirow[b]{2}{*}{$\mathrm{t}$} & \multirow[b]{2}{*}{ Sig. } \\
\hline & & $\mathrm{B}$ & Std. Error & Beta & & \\
\hline \multirow[t]{2}{*}{1} & (Constant) & .013 & 1.242 & & .010 & .992 \\
\hline & $\begin{array}{l}\text { Siklus } \\
\text { Operasi }\end{array}$ & .014 & .011 & .407 & 1.260 & .243 \\
\hline
\end{tabular}

a. Dependent Variable: likuiditas

Untuk mengetahui besarnya pengaruh antara siklus operasi terhadap likuiditas perusahaan dapat diketahui dari persamaan regresi yang diperoleh dari tabel diatas : $\mathrm{Y}=0,013-0,014 X$

Dimana : $\quad Y=$ Likuiditas

$\mathrm{X}=$ Siklus Operasi

Persamaan diatas menunjukkan bahwa siklus operasi memiliki pengaruh yang negatif terhadap likuiditas perusahaan. Persamaan diatas dapat diartikan bahwa setiap kenaikan siklus operasi sebesar 1 satuan maka likuiditas akan mengalami penurunan sebesar 0,014 sedangkan setiap penurunan siklus operasi masing-masing sebesar 1 satuan maka profitabilitas akan mengalami kenaikan sebesar 0,014. Intercept sebesar 0,013 menunjukkan bahwa apabila siklus operasi tidak mengalami perubahan maka likuiditas akan berada pada posisi yang stabil sebesar 0,013.

Dari tabel diatas maka dapat dilakukan uji $\mathrm{T}$ dengan ketentuan terdapat pengaruh yang signifikan apabila Thitung lebih besar dari Ttabel (Thitung > Ttabel). Uji T menunjukkan terdapat pengaruh yang signifikan antara nilai tukar rupiah terhadap profitabilitas perusahaan karena dari tabel diatas dapat dilihat Thitung statistic yang diperoleh sebesar 1,260 sedangkan Ttabel yang diperoleh sebesar 1,860. Hal ini dapat disimpulkan bahwa Thitung lebih kecil dibandingkan Ttabel $(1,260<1,860)$, maka hal ini mengindikasikan bahwa siklus operasi tidak memiliki pengaruh yang signifikan terhadap likuiditas perusahaan.

Selain dengan membandingkan antara Thitung dengan Ttabel, tingkat signifikansi juga dapat diketahui dengan membandingkan nilai Sig. pada table diatas dengan standar kesalahan atau alpha (a). Apabila nilai Sig. lebih kecil dari alpha (nilai Sig. < alpha) maka dapat dikatakan signifikan. Dalam penelitian ini penulis menggunakan alpha sebesar 0,05 dan Nilai Sig. Pada tabel diatas adalah 0,243 sehingga dapat dikatakan tidak terdapat pengaruh yang signifikan antara siklus 
operasi terhadap likuiditas perusahaan karena nilai Sig. lebih besar dibandingkan alpha $(0,243>0,05)$.

Dari uraian diatas hasil hipotesis statistik 1 adalah Ho1 diterima dan Ha1 ditolak dengan kesimpulan bahwa tidak ada pengaruh yang signifikan antara siklus operasi $\left(\mathrm{X}_{1}\right)$ terhadap likuiditas $(\mathrm{Y})$.

2. Pengaruh Siklus Konversi Kas terhadap Likuiditas Perusahaan

a. Pengaruh Siklus Konversi Kas terhadap Likuiditas PT. Mayora Indah, Tbk

Tabel 4

Coefficients siklus konversi kas terhadap likuiditas PT. Mayora Indah Tbk

Coefficients ${ }^{a}$

\begin{tabular}{|c|c|c|c|c|c|c|}
\hline \multirow{2}{*}{\multicolumn{2}{|c|}{ Model }} & \multicolumn{2}{|c|}{ Unstandardized Coefficients } & \multirow{2}{*}{$\begin{array}{c}\text { Standardized } \\
\text { Coefficients } \\
\text { Beta } \\
\end{array}$} & \multirow[b]{2}{*}{$\mathrm{t}$} & \multirow[b]{2}{*}{ Sig. } \\
\hline & & B & Std. Error & & & \\
\hline 1 & $\begin{array}{l}\text { (Constant) } \\
\text { siklus } \\
\text { konversi } \\
\text { kas }\end{array}$ & $\begin{array}{r}2.081 \\
.007\end{array}$ & $\begin{array}{r}1.042 \\
.012\end{array}$ & 208 & $\begin{array}{r}1.997 \\
.600\end{array}$ & $\begin{array}{l}.081 \\
.565\end{array}$ \\
\hline
\end{tabular}

a. Dependent Variable: Likuiditas

Untuk mengetahui besarnya pengaruh antara tnilai tukar rupiah terhadap profitabilitas perusahaan dapat diketahui dari persamaan regresi yang diperoleh dari tabel diatas :

$\mathrm{Y}=2,081+0,007 \mathrm{X}$

Dimana : $\quad Y=$ Likuiditas

$\mathrm{X}=$ Siklus Konversi Kas

Persamaan diatas menunjukkan bahwa sikulus konversi kas memiliki pengaruh yang negatif terhadap likuiditas perusahaan. Persamaan diatas dapat diartikan bahwa setiap kenaikan nilai tukar rupiah sebesar 1 satuan maka profitabilitas akan mengalami penurunan sebesar 0,007 sedangkan setiap penurunan siklus konversi kas masing-masing sebesar 1 satuan maka likuiditas akan mengalami kenaikan sebesar 0,007 . Intercept sebesar 2,081 menunjukkan bahwa apabila nilai tukar rupiah tidak mengalami perubahan maka likuiditas akan berada pada posisi yang stabil sebesar 2,081 .

Dari tabel diatas maka dapat dilakukan uji $\mathrm{T}$ dengan ketentuan terdapat pengaruh yang signifikan apabila Thitung lebih besar dari Ttabel (Thitung $>$ Ttabel). Uji T menunjukkan terdapat pengaruh yang signifikan antara siklus konversi kas terhadap likuiditas perusahaan karena dari tabel diatas dapat dilihat Thitung statistic yang diperoleh sebesar 0,600 sedangkan Ttabel yang diperoleh sebesar 1,860. Hal ini dapat disimpulkan bahwa Thitung lebih kecil dibandingkan Ttabel $(0,600<1,860)$, maka hal ini mengindikasikan bahwa siklus konversi kas tidak memiliki pengaruh yang signifikan terhadap likuiditas perusahaan.

Selain dengan membandingkan antara Thitung dengan Ttabel, tingkat signifikansi juga dapat diketahui dengan membandingkan nilai Sig. pada table diatas dengan standar kesalahan atau alpha (a). Apabila nilai Sig. lebih kecil dari alpha (nilai Sig. < alpha) maka dapat dikatakan signifikan. Dalam penelitian ini penulis menggunakan alpha sebesar 0,05 dan Nilai Sig. Pada tabel diatas adalah 0,565 sehingga dapat dikatakan tidak terdapat pengaruh yang signifikan antara siklus konversi kas terhadap likuiditas perusahaan karena nilai Sig. lebih kecil dibandingkan alpha $(0.565>0,05)$.

Dari uraian diatas hasil hipotesis statistik 2 adalah Ho1 diterima dan Ha1 ditolak dengan kesimpulan bahwa ada pengaruh yang tidak signifikan antara Siklus konversi kas $\left(\mathrm{X}_{2}\right)$ terhadap Likuiditas $(\mathrm{Y})$. 
b. Pengaruh Siklus Konversi Kas terhadap Likuiditas PT. Ultrajaya Milk Industry \& Trading Co Tbk

Tabel 5

Coefficients SKK terhadap likuiditas PT. Ultrajaya Milk Industry \& Trading Co Tbk

Coefficients ${ }^{a}$

\begin{tabular}{|c|c|c|c|c|c|c|}
\hline \multirow{2}{*}{\multicolumn{2}{|c|}{ Model }} & \multicolumn{2}{|c|}{ Unstandardized Coefficients } & $\begin{array}{l}\text { Standardized } \\
\text { Coefficients }\end{array}$ & \multirow[b]{2}{*}{$c$} & \multirow[b]{2}{*}{ Sig. } \\
\hline & & $\mathrm{B}$ & Std. Error & Beta & & \\
\hline \multirow[t]{2}{*}{1} & (Constant) & 2.198 & .447 & & 4.918 & .001 \\
\hline & $\begin{array}{l}\text { Siklus } \\
\text { konversi } \\
\text { kas }\end{array}$ & -.002 & .005 & -.130 & -.371 & .720 \\
\hline
\end{tabular}

a. Dependent Variable: likuditas

Untuk mengetahui besarnya pengaruh antara tnilai tukar rupiah terhadap profitabilitas perusahaan dapat diketahui dari persamaan regresi yang diperoleh dari tabel diatas :

$Y=2,198+-0,002 X$

Dimana : $\quad Y=$ Likuiditas

$X=$ Siklus Konversi Kas

Persamaan diatas menunjukkan bahwa sikulus konversi kas memiliki pengaruh yang negatif terhadap likuiditas perusahaan. Persamaan diatas dapat diartikan bahwa setiap kenaikan nilai tukar rupiah sebesar 1 satuan maka profitabilitas akan mengalami penurunan sebesar -0,002 sedangkan setiap penurunan siklus konversi kas masing-masing sebesar 1 satuan maka likuiditas akan mengalami kenaikan sebesar 0,002. Intercept sebesar 2,198 menunjukkan bahwa apabila nilai tukar rupiah tidak mengalami perubahan maka likuiditas akan berada pada posisi yang stabil sebesar 2,198 .

Dari tabel diatas maka dapat dilakukan uji $\mathrm{T}$ dengan ketentuan terdapat pengaruh yang signifikan apabila Thitung lebih besar dari Ttabel (Thitung > Ttabel). Uji $T$ menunjukkan terdapat pengaruh yang signifikan antara siklus konversi kas terhadap likuiditas perusahaan karena dari tabel diatas dapat dilihat Thitung statistic yang diperoleh sebesar -0,371 sedangkan Ttabel yang diperoleh sebesar 1,860. Hal ini dapat disimpulkan bahwa Thitung lebih kecil dibandingkan Ttabel $(-0,371<1,860)$, maka hal ini mengindikasikan bahwa siklus konversi kas tidak memiliki pengaruh yang signifikan terhadap likuiditas perusahaan.

Selain dengan membandingkan antara Thitung dengan Ttabel, tingkat signifikansi juga dapat diketahui dengan membandingkan nilai Sig. pada table diatas dengan standar kesalahan atau alpha (a). Apabila nilai Sig. lebih kecil dari alpha (nilai Sig. < alpha) maka dapat dikatakan signifikan. Dalam penelitian ini penulis menggunakan alpha sebesar 0,05 dan Nilai Sig. Pada tabel diatas adalah 0,720 sehingga dapat dikatakan tidak terdapat pengaruh yang signifikan antara siklus konversi kas terhadap likuiditas perusahaan karena nilai Sig. lebih kecil dibandingkan alpha $(0,720>0,05)$.

Dari uraian diatas hasil hipotesis statistik 2 adalah Ho1 diterima dan Ha1 ditolak dengan kesimpulan bahwa ada pengaruh yang tidak signifikan antara Siklus konversi kas $\left(\mathrm{X}_{2}\right)$ terhadap Likuiditas $(\mathrm{Y})$. 
Tabel 6

Coefficients siklus konversi kas terhadap likuiditas PT. Sekar Laut Tbk

\section{Coefficients $^{a}$}

\begin{tabular}{|c|c|c|c|c|c|c|}
\hline \multirow{2}{*}{\multicolumn{2}{|c|}{ Model }} & \multicolumn{2}{|c|}{ Unstandardized Coefficients } & $\begin{array}{c}\text { Standardized } \\
\text { Coefficients }\end{array}$ & \multirow[b]{2}{*}{$\mathrm{t}$} & \multirow[b]{2}{*}{ Sig. } \\
\hline & & $\mathrm{B}$ & Std. Error & Beta & & \\
\hline \multirow[t]{2}{*}{1} & (Constant) & .784 & .406 & & 1.928 & .090 \\
\hline & $\begin{array}{l}\text { Siklus } \\
\text { konversi } \\
\text { kas }\end{array}$ & .013 & .007 & .573 & 1.976 & .084 \\
\hline
\end{tabular}

a. Dependent Variable: y

Untuk mengetahui besarnya pengaruh antara tnilai tukar rupiah terhadap profitabilitas perusahaan dapat diketahui dari persamaan regresi yang diperoleh dari tabel diatas :

$Y=0,784+0,013 X$

Dimana : $\quad Y=$ Likuiditas

$\mathrm{X}=$ Siklus Konversi Kas

Persamaan diatas menunjukkan bahwa sikulus konversi kas memiliki pengaruh yang negatif terhadap likuiditas perusahaan. Persamaan diatas dapat diartikan bahwa setiap kenaikan nilai tukar rupiah sebesar 1 satuan maka profitabilitas akan mengalami penurunan sebesar -0,013 sedangkan setiap penurunan siklus konversi kas masing-masing sebesar 1 satuan maka likuiditas akan mengalami kenaikan sebesar 0,013. Intercept sebesar 0,784 menunjukkan bahwa apabila nilai tukar rupiah tidak mengalami perubahan maka likuiditas akan berada pada posisi yang stabil sebesar 0,784 .

Dari tabel diatas maka dapat dilakukan uji $\mathrm{T}$ dengan ketentuan terdapat pengaruh yang signifikan apabila Thitung lebih besar dari Ttabel (Thitung > Ttabel). Uji T menunjukkan terdapat pengaruh yang signifikan antara siklus konversi kas terhadap likuiditas perusahaan karena dari tabel diatas dapat dilihat Thitung statistic yang diperoleh sebesar 1.974 sedangkan Ttabel yang diperoleh sebesar 1,860 . Hal ini dapat disimpulkan bahwa Thitung lebih kecil dibandingkan Ttabel $(1,974>1,860)$, maka hal ini mengindikasikan bahwa siklus konversi kas memiliki pengaruh yang signifikan terhadap likuiditas perusahaan.

Selain dengan membandingkan antara Thitung dengan Ttabel, tingkat signifikansi juga dapat diketahui dengan membandingkan nilai Sig. pada table diatas dengan standar kesalahan atau alpha (a). Apabila nilai Sig. lebih kecil dari alpha (nilai Sig. < alpha) maka dapat dikatakan signifikan. Dalam penelitian ini penulis menggunakan alpha sebesar 0,05 dan Nilai Sig. Pada tabel diatas adalah 0,084 sehingga dapat dikatakan tidak terdapat pengaruh yang signifikan antara siklus konversi kas terhadap likuiditas perusahaan karena nilai Sig. lebih kecil dibandingkan alpha $(0,084>0,05)$.

Dari uraian diatas hasil hipotesis statistik 2 adalah Ho1 diterima dan Ha1 ditolak dengan kesimpulan bahwa ada pengaruh yang tidak signifikan antara Siklus konversi kas $\left(\mathrm{X}_{2}\right)$ terhadap Likuiditas $(\mathrm{Y})$.

\section{Pengaruh Siklus Operasi dan Siklus Konversi Kas terhadap Likuiditas Perusahaan}

a. Pengaruh Siklus Operasi dan Siklus Konversi Kas terhadap Likuiditas PT. Mayra Indah Tbk 
Tabel 7

Coefficients SO dan SKK terhadap likuiditas PT. Mayora Indah Tbk

Coefficients ${ }^{a}$

\begin{tabular}{|c|c|c|c|c|c|c|}
\hline \multirow{2}{*}{\multicolumn{2}{|c|}{ Model }} & \multicolumn{2}{|c|}{ Unstandardized Coefficients } & \multirow{2}{*}{$\begin{array}{c}\begin{array}{c}\text { Standardized } \\
\text { Coefficients }\end{array} \\
\text { Beta }\end{array}$} & \multirow[b]{2}{*}{$\mathrm{t}$} & \multirow[b]{2}{*}{ Sig. } \\
\hline & & $\mathrm{B}$ & Std. Error & & & \\
\hline \multirow[t]{3}{*}{1} & (Constant) & 3.421 & 2.432 & & 1.406 & .202 \\
\hline & SO & -.022 & .036 & -.530 & -.615 & .558 \\
\hline & SKK & .024 & .029 & .689 & .800 & .450 \\
\hline
\end{tabular}

a. Dependent Variable: likuiditas

Untuk mengetahui besarnya pengaruh antara tingkat inflasi dan nilai tukar rupiah terhadap profitabilitas perusahaan dapat diketahui dari persamaan regresi yang diperoleh dari tabel diatas :

$\mathrm{Y}=3,421-0,022 X 1-0,024 X 2$

Dimana : $\quad Y=$ Likuiditas

X1 = Siklus Operasi

$\mathrm{X} 2$ = Siklus Konversi Kas

Persamaan diatas menunjukkan bahwa siklus operasi dan siklus konversi kas memiliki pengaruh yang negatif terhadap likuiditas perusahaan. Persamaan diatas dapat diartikan bahwa setiap kenaikan siklus operasi dan siklus konversi kas masingmasing sebesar 1 satuan maka likuiditas akan mengalami penurunan sebesar $-0,022$ dan 0,024 sedangkan setiap penurunan siklus operasi dan siklus konversi kas masingmasing sebesar 1 satuan maka profitabilitas akan mengalami kenaikan sebesar $-0,022$ dan 0,024. Intercept sebesar 3,421 menunjukkan bahwa apabila siklus operasi dan siklus konversi kas tidak mengalami perubahan maka likuiditas akan berada pada posisi yang stabil sebesar 3,421.

Berdasarkan hasil tersebut maka siklus operasi tidak memiliki pengaruh yang signifikan terhadap likuiditas perusahaan karena nilai thitung sebesar $-0,022$ lebih kecil dari ttabel dengan tingkat kepercayaan yaitu 5\% sebesar 1,860, dan siklus konversi kas tidak memiliki pengaruh yang signifikan karena thitung sebesar 0,024 lebih kecil dari ttabel dengan tingkat kepercayaan $5 \%$ sebesar 1,860 . Maka hal ini mengindikasikan bahwa siklus konversi kas tidak memiliki pengaruh signifikan terhadap likuiditas perusahaan.

Dari analisis diatas maka dapat disimpulkan bahwa antara siklus operasi dan siklus konversi kas secara simultan terhadap likuiditas perusahaan tidak memiliki pengaruh yang signifikan.

Dari uraian diatas hasil hipotesis statistik 3 adalah Ho1 diterima dan Ha1 ditolak dengan kesimpulan bahwa tidak ada pengaruh yang signifikan antara Siklus operasi $\left(\mathrm{X}_{1}\right)$ dan Siklus konversi kas $\left(\mathrm{X}_{2}\right)$ terhadap Likuiditas $(\mathrm{Y})$.

b. Pengaruh Siklus Operasi dan Siklus Konversi Kas terhadap Likuiditas PT. Ultrajaya Milk Industry \& Trading Co Tbk

Tabel 8

Coefficients SO dan SKK terhadap likuiditas PT. Ultrajaya Milk Industry \& Trading Co, Tbk

Coefficients $^{a}$

\begin{tabular}{|c|c|c|c|c|c|}
\hline \multirow[t]{2}{*}{ Model } & \multicolumn{2}{|c|}{ Unstandardized Coefficients } & $\begin{array}{c}\text { Standardized } \\
\text { Coefficients }\end{array}$ & \multirow[b]{2}{*}{$\mathrm{t}$} & \multirow[b]{2}{*}{ Sig. } \\
\hline & $\mathrm{B}$ & Std. Error & Beta & & \\
\hline (Constant) & 3.826 & 1.853 & & 2.064 & .078 \\
\hline so & -.017 & .019 & -.748 & -.906 & .395 \\
\hline SKK & .008 & .012 & .545 & .661 & .530 \\
\hline
\end{tabular}

a. Dependent Variable: Likuiditas 
Untuk mengetahui besarnya pengaruh antara siklus operasi dan siklus konversi kas terhadap likuiditas perusahaan dapat diketahui dari persamaan regresi yang diperoleh dari tabel diatas :

$\mathrm{Y}=3,826-0,017 X 1-0,008 X 2$

Dimana : $\quad Y=$ Likuiditas

$\mathrm{X} 1$ = Siklus Operasi

$\mathrm{X} 2$ = Siklus Konversi Kas

Persamaan diatas menunjukkan bahwa siklus operasi dan siklus konversi kas memiliki pengaruh yang negatif terhadap likuiditas perusahaan. Persamaan diatas dapat diartikan bahwa setiap kenaikan siklus operasi dan siklus konversi kas masingmasing sebesar 1 satuan maka likuiditas akan mengalami penurunan sebesar $-0,017$ dan 0,008 sedangkan setiap penurunan siklus operasi dan siklus konversi kas masingmasing sebesar 1 satuan maka profitabilitas akan mengalami kenaikan sebesar $-0,017$ dan 0,008. Intercept sebesar 3,826 menunjukkan bahwa apabila siklus operasi dan siklus konversi kas tidak mengalami perubahan maka likuiditas akan berada pada posisi yang stabil sebesar 3,826.

Berdasarkan hasil tersebut maka siklus operasi tidak memiliki pengaruh yang signifikan terhadap likuiditas perusahaan karena nilai thitung sebesar -0,017 lebih kecil dari ttabel dengan tingkat kepercayaan yaitu $5 \%$ sebesar 1,860 , dan siklus konversi kas tidak memiliki pengaruh yang signifikan karena thitung sebesar 0,008 lebih kecil dari ttabel dengan tingkat kepercayaan 5\% sebesar 1,860. Maka hal ini mengindikasikan bahwa siklus konversi kas tidak memiliki pengaruh signifikan terhadap likuiditas perusahaan.

Dari analisis diatas maka dapat disimpulkan bahwa antara siklus operasi dan siklus konversi kas secara simultan terhadap likuiditas perusahaan tidak memiliki pengaruh yang signifikan.

Dari uraian diatas hasil hipotesis statistik 3 adalah Ho1 diterima dan Ha1 ditolak dengan kesimpulan bahwa tidak ada pengaruh yang signifikan antara Siklus operasi $\left(\mathrm{X}_{1}\right)$ dan Siklus konversi kas $\left(\mathrm{X}_{2}\right)$ terhadap Likuiditas $(\mathrm{Y})$.

c. Pengaruh Siklus Operasi dan Siklus Konversi Kas terhadap Likuiditas PT. Sekar Laut, Tbk

Tabel 9

Coefficients SO dan SKK terhadap likuiditas PT. Sekar Laut Tbk

Coefficients ${ }^{a}$

\begin{tabular}{|c|c|c|c|c|c|c|}
\hline \multirow{2}{*}{\multicolumn{2}{|c|}{ Model }} & \multicolumn{2}{|c|}{ Unstandardized Coefficients } & $\begin{array}{c}\text { Standardized } \\
\text { Coefficients }\end{array}$ & \multirow[b]{2}{*}{$\mathrm{t}$} & \multirow[b]{2}{*}{ Sig. } \\
\hline & & $\mathrm{B}$ & Std. Error & Beta & & \\
\hline \multirow[t]{3}{*}{1} & (Constant) & .008 & 1.149 & & .007 & .994 \\
\hline & $\mathrm{X} 1$ & .008 & .011 & .232 & .725 & .492 \\
\hline & $\times 2$ & .011 & .007 & .490 & 1.531 & .170 \\
\hline
\end{tabular}

a. Dependent Variable: y

Untuk mengetahui besarnya pengaruh antara siklus operasi dan siklus konversi kas terhadap likuiditas perusahaan dapat diketahui dari persamaan regresi yang diperoleh dari tabel diatas:

$Y=0,008-0,008 X 1-0,011 X 2$

Dimana : $\quad Y=$ Likuiditas

$\mathrm{X} 1$ = Siklus Operasi

X2 = Siklus Konversi Kas

Persamaan diatas menunjukkan bahwa siklus operasi dan siklus konversi kas memiliki pengaruh yang negatif terhadap likuiditas perusahaan. Persamaan diatas dapat diartikan bahwa setiap kenaikan siklus operasi dan siklus konversi kas masingmasing sebesar 1 satuan maka likuiditas akan mengalami penurunan sebesar 0,008 dan 0,011 sedangkan setiap penurunan siklus operasi dan siklus konversi kas masingmasing sebesar 1 satuan maka profitabilitas akan mengalami kenaikan sebesar 0,008 dan 0,011. Intercept sebesar 0,008 menunjukkan bahwa apabila siklus operasi dan 
siklus konversi kas tidak mengalami perubahan maka likuiditas akan berada pada posisi yang stabil sebesar 0,008.

Berdasarkan hasil tersebut maka siklus operasi tidak memiliki pengaruh yang signifikan terhadap likuiditas perusahaan karena nilai thitung sebesar 0,008 lebih kecil dari ttabel dengan tingkat kepercayaan yaitu $5 \%$ sebesar 1,860 , dan siklus konversi kas tidak memiliki pengaruh yang signifikan karena thitung sebesar 0,011 lebih kecil dari ttabel dengan tingkat kepercayaan $5 \%$ sebesar 1,860. Maka hal ini mengindikasikan bahwa siklus konversi kas tidak memiliki pengaruh signifikan terhadap likuiditas perusahaan.

Dari analisis diatas maka dapat disimpulkan bahwa antara siklus operasi dan siklus konversi kas secara simultan terhadap likuiditas perusahaan tidak memiliki pengaruh yang signifikan.

Dari uraian diatas hasil hipotesis statistik 3 adalah Ho1 diterima dan Ha1 ditolak dengan kesimpulan bahwa tidak ada pengaruh yang signifikan antara Siklus operasi $\left(X_{1}\right)$ dan Siklus konversi kas $\left(X_{2}\right)$ terhadap Likuiditas $(Y)$.

\section{KESIMPULAN}

Berdasarkan hasil analisis dan pembahasan pada bab IV yang diperoleh dari PT. Mayora Indah Tbk, PT Ultrajaya Milk Industry \& Trading Company Tbk, dan PT. Sekar Laut Tbk maka penulis mengambil kesimpulan sebagai berikut:

1. Hasil analisis dari ketiga perusahaan yaitu PT. Mayora Indah Tbk, PT. Ultrajaya Milk Indutry \& Trading Co Tbk dan PT. Sekar Laut Tbk. yang diukur dengan menggunakan tiga variabel yaitu siklus operasi dan siklus konversi kas terhadap likuiditas. Dengan ketiga perusahaan tersebut PT. Sekar Laut yang lebih baik di bandingkan dengan PT. Mayora Indah Tbk dan PT. Ultrajaya Milk Indutry \& Trading Co Tbk karena PT. Sekar Laut lebih baik dalam pengelolaan piutang untuk dijadikan kas dan dapat memanfaat persediaan yang ada serta perusahaan mampu melakukan perencanaan dan pengendalian aktiva lancar dan hutang lancarnya.

2. Pengaruh siklus operasi terhadap likuiditas perusahaan Berdasarkan hasil uji t (parsial) statistik terhadap ketiga perusahaan yang diteliti penulis menunjukkan bahwa pengaruh sikus operasi terhadap likuiditas yang diwakili oleh Current Ratio PT. Mayora Indah Tbk, PT. Ultrajaya Milk Industry \& Trading co Tbk, dan PT. Sekar Laut Tbk, tidak memiliki pengaruh yang signifikan. Dari ketiga perusahaan tersebut, PT. Sekar Laut Tbk, memiliki nilai sig. terkecil, yaitu sebesar 0,243 dengan standar kesalahan atau alpha (a) sebesar 5\%, sedangkan koefisien korelasi PT. Sekar Laut Tbk, sebesar 0,407 yang berarti 40,7\%. Dan diperoleh koefisien determinasi (R square) sebesar 0,166 yang berarti $16,6 \%$ likuiditas PT. Sekar Laut Tbk, dipengaruhi oleh siklus operasi. Sedangkan sisanya $83 \%$ dipengaruhi oleh variabel lain selain siklus operasi.

3. Pengaruh siklus konversi kas terhadap likuiditas perusahaan

Berdasarkan hasil t (persial) statistic terhadap ketiga perusahaan yang diteiliti penulis menunjukkan bahwa pengaruh siklus konversi kas terhadapa likuiditas yang diwakili oleh Current Ratio PT. Mayora Indah Tbk, PT. Ultrajaya Milk Industry \& Trading co Tbk, dan PT. Sekar Laut Tbk, tidak memiliki pengaruh yang signifikan. Dari ketiga perusahaan tersebut, PT. sekar Laut Tbk, memiliki nilai sig. terkecil, yaitu sebesar 0,084 dengan standar kesalahan atau alpha (a) sebesar $5 \%$, sedangkan koefisien korelasi sebesar 0,573 yang berarti $57,3 \%$. Dan diperoleh koefisien determinasi ( $R$ square) sebesar 0,328 yang berarti $32,8 \%$ likuiditas PT. Sekar Laut Tbk, dipengaruhi oleh siklus operasi. Sedangkan sisanya $67,2 \%$ dipengaruhi oleh variabel lain selain siklus konversi kas.

4. Pengaruh siklus operasi dan siklus konversi kas terhadap likuiditas perusahaan Berdasrakan hasil uji f (simultan) statistik terhadap ketiga perusahaan yang diteliti penulis menunjukkan bahwa pengaruh siklus operasi dan siklus konversi kas terhadap likuiditas yang diwakili Current Ratio PT. Mayora Indah Tbk, PT. Ultrajaya Milk Industry \& Trading co Tbk, dan PT. Sekar Laut Tbk, tidak memiliki pengaruh yang signifikan. Dari ketiga perusahaan tersebut, PT. Sekar Laut Tbk, memiliki nilai sig. terkecil yaitu sebesar 0,193 dengan standar 
kesalahan atau alpha (a) sebra 5\%, sedangkan koefisien korelasi sebesar 0,612 yang berarti $61,2 \%$. Dan diperoleh koefisien determinasi ( $R$ square) sebesar 0,375 yang berarti $37,5 \%$. Angka tersebut memberikan penjelasan bahwa $37.5 \%$ likuiditas dipengaruhi oleh siklus operasi dan siklus konversi kas. Sedangkan sisanya $62,5 \%$ dipengaruhi oleh variabel lain selain siklus operasi dan siklus konversi kas.

\section{SARAN}

Setelah melakukan penelitian ini, adapun saran yang dapat diberikan peneliti:

1. Saran yang penulis sampaikan untuk PT. Mayora Indah Tbk, PT. Ultrajaya Milk Industry \& Co Trading tbk, dan PT. Sekar Laut Tbk harus lebih baik lagi dalam proses produksinya agar dapat menghasilkan aliran kas masuk dengan tidak terlambat sehingga akan meningkatkan penjualan yang semakin meningkat dari tahun ke tahun.

2. Ketiga perusahaan tersebut juga harus dapat mengelola modal kerjanya dengan baik agar perusahaan dapat membayar hutang lancarnya sehingga perusahaan dapat dikatakan likuid.

3. Penelitian ini hanya menggunakan dua variabel independen dan satu variabel dependen, peneliti selanjutnya dapat menambah dan mengembangkan jumlah variabel baik independen dan dependen. Penelitian ini menggunakan model penelitian analisis regresi berganda, peneliti berharap peneliti selanjutnya untuk dapat menggunakan dan mengembangkan model lain dalam penelitian selanjutnya.

\section{DAFTAR PUSTAKA}

Arief.Sugiono.2009. Manajemen Keuangan untuk Praktis Keuangan. Gramedia widia sarana. Jakarta.

Baridwan, Zaki, 2004. Intermediate Accounting. Edisi ketujuh. Cetakan kelima. Yogyakarta : BPEE

Bodnar, George H, dan William S. hopwood 2006. System Informasi Akuntansi, Edisi Sembilan, PT. Indeks Kelompok, Andi, Yogyakarta.

Erlina dan Sri Mulyani, 2007. Metodologi Penelitian Bisnis, USU Perss, Medan, hal 41 dan 42.

Gitman, Lawrence J. 2009. Principle of Managarial Finance. Twelfth Edition. Prentice Hall.

Harahap, Sofyansyafitri. 2010. Analisis Kritis atas Laporan Keuangan, PT. Raja Grafindo Persada, Jakarta.

Kasmir, 2012. Analisis Laporan Keuangan. PT Raja Grafindo Persada, Jakarta.

Mulyana, M. and Puspitasari, R., 2014. Analisis Faktor-faktor Yang Membentuk Minat Berwirausaha Siswa SMK di Kota Bogor.

Mulyana, M. and Maulana, M., 2013. Pengaruh Pelayanan Terhadap Kepuasan Pelanggan dan Implikasinya Terhadap Citra Perusahaan. Jurnal IImiah Manajemen Kesatuan, 1(2).

Pedro, J dan Pendo, M 2007. Effects Of working Capital Management On SME Profitability, International Journal Of Managerial Finance, Vol 31552 PP. 164177.

Riawati (Universitas Maritim Raja Ali Haji Tanjungpinang) Pengaruh Jumlah Kas, Siklus Konversi Kas dan Growth Sale terhadap Likuiditas (Pada Perusahaan Automotive And ALlied Products yang terdaftar Di Bursa Efek Indonesia Periode 2007-2011).

Syanty Octavia (Universitas Kristen Petra) Analisa Siklus Operasi terhadap Likuiditas (Pada Perusahaan Makanan dan minuman yang Listing di Bursa Efek Jakarta).

Subramanyam, K.R dan John, Wild 2010 Analisis Laporan Keuangan, Edisi kesepuluh, Salemba Empat, Jakarta.

Sri Dwi Ari Ambarwati. 2010. Manajemen Keuangan Lanjutan. Yogyakarta: Graha Ilmu. 
Sugiono, Arief. 2009. Manajemen Keuangan untuk Praktis Keuangan, Pt Grasindo, Jakarta.

Van Hom. James C and Jhon M. Wachowics. Jr. 2005. Foundamentals Of Financial Managemen, Tenth edition. New Jersey. Prentise Hall inc.

Warren, Reeve, dan Fress 2008 Pengantar Akuntansi Edisi 21, Salemba empat. Jakarta. 